\title{
Effects of Soda-Lime-Silica Glass and Borax Decahydrate as Alternative Fluxing Agents on the Stoneware Physico-Mechanical Properties
}

\author{
S. Natrah ${ }^{1}$, R. Hussin ${ }^{2 *}$ and A. B. Aramjat ${ }^{3}$ \\ ${ }^{1}$ Department of Materials and Design Engineering, Faculty of Mechanical and \\ Manufacturing, Universiti Tun Hussein Onn, 86400, Parit Raja, Batu Pahat, Johor \\ *Email: natrahutm2000@yahoo.com \\ ${ }^{2}$ Faculty of Engineering Technology, Universiti Tun Hussein Onn, 86400, Parit Raja, \\ Batu Pahat, Johor \\ ${ }^{3}$ Kolej Kemahiran Tinggi Mara, Masjid Tanah, Jalan Ramuan China Besar, 78300, \\ Lubuk China, Melaka
}

\begin{abstract}
Stoneware especially tableware is manufactured by mixing the clay, quartz and flux such as feldspar. Thus, the aim of this work is to investigate the possibility of two alternative fluxing agents namely; soda-lime-silica glass (SLS), and borax decahydrate (BD) on characterization, and physico-mechanical properties of stoneware to demonstrate its suitability for tableware production. SLS and BD are incorporated into stoneware at the dosage of $5 \%$, and $10 \%$ by weight, respectively. The sample was performed by uniaxial pressing (40 MPa) sintered at $1000,1050,1100$, and $1150^{\circ} \mathrm{C}$ (2 hours soaking time) to establish minimum sintering temperature. Bulk density, water absorption, and modulus of rupture (MOR) were measured for each sample. Characterization of XRF, XRD, and SEM was carried out and discussed. Results indicated SLS, BD showed higher physicomechanical properties and vitrified at $1050-1100^{\circ} \mathrm{C}$, lower than normal temperature applied for stoneware $\left(1150^{\circ} \mathrm{C}\right)$. Consequently, it was determined that the usage of SLS and $\mathrm{BD}$ as fluxing agent in stoneware is possible.
\end{abstract}

Keywords: Flux; sintering; stoneware; temperature; soda-lime-silica glass; borax decahydrate.

\section{INTRODUCTION}

Generally, stoneware is sintered at $1200^{\circ} \mathrm{C}$ to $1300^{\circ} \mathrm{C}$ basically white, ivory or light grey in appearance. It has excellent properties such as high bulk density and low water absorption [1,2]. Typically, stoneware consists of $\mathrm{SiO}_{2}$ and $\mathrm{Al}_{2} \mathrm{O}_{3}$ as major oxides with minor amount of $\mathrm{CaO}, \mathrm{Na}_{2} \mathrm{O}$ and $\mathrm{MgO}$. Specifically, stoneware is formulated from three basic components (clay, quartz and feldspar). In this connection, clay induces plasticity on the green body and simultaneously mullite formation upon sintering process. Fillers such as quartz control the deformation and shrinkage. While feldspars such as sodium $\left(\mathrm{NaAlSi}_{3} \mathrm{O}_{8}\right)$, potassium $\left(\mathrm{KAlSi}_{3} \mathrm{O}_{8}\right)$ and calcium $\left(\mathrm{CaAlSi}_{3} \mathrm{O}_{8}\right)$ acted as flux to reduce the sintering temperature through the formation of both glassy and crystalline phase $[3,4]$.

As a matter of fact, stoneware especially tableware industry is aiming for producing high quality and present environmentally sustainable product. The strength of stoneware usually given in term modulus of rupture (MOR) which more than 50MPa, low water absorption (0-5\%) and bulk density $\left(2.3 \mathrm{~g} / \mathrm{cm}^{3}\right)$. In the context of global competition, the challenge for stoneware industry is mainly directed towards reduction of 
capital while maintaining or even improving the quality and properties of the end product. Thus, one of the important approaches to overcome this problem is to replace the traditional feldspar with alternative fluxing agents [5,6]. Numerous technologies have been developing to replace traditional feldspar with alternative fluxing agents such as zeolite [7], untreated coffee [8], illite [9], soda-lime-silica glass [10] and borax [11]. Among all the alternative fluxes, soda-lime-silica glass or borax decahydrate attracts more research interest due to less iron content $\left(\mathrm{Fe}_{2} \mathrm{O}_{3}\right)$, similar chemical composition and availability in large amount as waste material.

Soda-lime-silica glass or glass cullet among the silica glass from bottle banks has attracted much attention [12,13]. Generally, the major constituents of soda-lime-silica glass are silica $\left(\mathrm{SiO}_{2}\right)$, sodium oxide $\left(\mathrm{Na}_{2} \mathrm{O}\right)$, and lime oxide $(\mathrm{CaO})$. Additionally, the melting point of soda-lime-silica glass is approximately $700^{\circ} \mathrm{C}$ [14]. On top of that, when soda-lime-silica glass is incorporated into a mixture, it has a strong tendency of becoming a fluxing agent to substitute feldspar and obtain vitreous microstructure [15]. On the other hand, borax decahydrate is a hydrous sodium borate mineral or tetraborate. The term decahydrate specifically means a hydrate that contains ten molecules of water. Borax decahydrate usually contains aluminium ( $\mathrm{Al}$ ) followed by boron (B) and sodium $(\mathrm{Na})$. Besides, borax decahydrate also has a monoclinic crystal structure with the chemical composition of $\mathrm{Na}_{2} \mathrm{~B}_{4} \mathrm{O}_{7} \cdot 10 \mathrm{H}_{2} \mathrm{O}$. The melting point of borax decahydrate is approximately $600^{\circ} \mathrm{C}[16,17]$. Therefore, the main objective of this study was to determine potential of soda-lime-silica glass and borax decahydrate as alternative fluxing agent on characterisation, physico-mechanical properties of stoneware.

\section{EXPERIMENTAL SET UP}

To begin with, the raw materials (ST) were obtained from stoneware industry in Malaysia and dried in an oven (PF20, Carbolite) $110{ }^{\circ} \mathrm{C}$ for 24 hours. These materials were then crushed (Los Angeles Abrasion Crusher) to yield a powder with a particle size $<80 \mu \mathrm{m}$ with $800 \mathrm{rpm}$ speed. The chemical composition of raw material from stoneware, sodalime-silica glass was determined by using X-ray fluorescence (XRF, Oxford Instrument Model X-supreme 8000) while inductive coupled plasma-mass spectrometry (ICP-MS, Agilent 7500) analysis was used for borax decahydrate. The phase shown in the sample was assessed from XRD pattern. The pattern was recorded using Rigaku Ultima IV Model with $\mathrm{CuK} \alpha$ radiation $\lambda=1.514$ in scanning range of $2 \theta^{\circ}=5^{\circ}-90^{\circ}$. The different mixes were prepared by milling the ST with SLS and BD in porcelain jar mill for 30 minutes. The sample was labelled as ST for industry stoneware while SLS5, SLS10, BD5, and BD10 were for industry stoneware with additional $5 \mathrm{wt} \%$ and $10 \mathrm{wt} \%$ of SLS and BD. To produce 8gram of rectangular sample with $5.5 \mathrm{~mm}$ height, sample was pressed in rectangular die-pressing of $65 \mathrm{~mm}$ x $12 \mathrm{~mm}$ under $40 \mathrm{MPa}$ pressure with 1 minute holding time using Carver Bench Top Standard Auto Series. The pressed sample was dried at room temperature for 24 hours. The sample was then sintered in electric furnace between $950^{\circ} \mathrm{C}$ to $1150^{\circ} \mathrm{C}$ using heating rate of $5 \mathrm{C} / \mathrm{min}$ and 2 hours soaking time. Sample was left to free cooling at room temperature.

Bulk density and water absorption were determined by Archimedes immersion method in water as described in the ASTM C373-88 standard. The modulus of rupture (MOR) of sintered sample was measured at loading of $1 \mathrm{~mm} / \mathrm{min}$ by three-point bending test (Geotech AI-7000S). The microstructures of the sintered samples were observed by scanning electron microscopy, SEM (Hitachi SU1510). Before SEM observation, sample was etched using HF $4 \%$ for 3 seconds and Au-pd coated. 


\section{RESULTS AND DISCUSSION}

Table 1 shows the list of chemical composition of the sample based on X-ray fluorescence and inductively coupled plasma-mass spectrometry. For raw material and soda-limesilica-glass, the major components are silica as expected. As for borax decahydrate, the major components are boron and sodium.

Table 1. Chemical composition (wt \%) of stoneware, soda-lime-silica glass and borax decahydrate.

\begin{tabular}{llllllllllll}
\hline $\begin{array}{l}\text { Raw } \\
\text { material }\end{array}$ & $\mathrm{SiO}_{2}$ & $\begin{array}{l}\mathrm{Al}_{2} \\
\mathrm{O}_{3}\end{array}$ & $\begin{array}{l}\mathrm{Na}_{2} \\
\mathrm{O}\end{array}$ & $\mathrm{K}_{2} \mathrm{O}$ & $\mathrm{CaO}$ & $\begin{array}{l}\mathrm{Mg} \\
\mathrm{O}\end{array}$ & $\begin{array}{l}\mathrm{Fe}_{2} \\
\mathrm{O}_{3}\end{array}$ & $\mathrm{Al}$ & $\mathrm{Na}$ & $\mathrm{B}$ & $\mathrm{Ca}$ \\
\hline Stoneware & 66.5 & 26.6 & 1.57 & 2.49 & 0.43 & 0.76 & 0.76 & & & & \\
(g) & 4 & 6 & 18.1 & 0.33 & 6.92 & 2.65 & 0.07 & & & & \\
$\begin{array}{l}\text { Soda- } \\
\text { lime-(g) }\end{array}$ & 69.2 & 2.25 & 7 & & & & & & & & \\
silica glass & & & & & & & & & & & \\
$\begin{array}{l}\text { Borax (g) } \\
\text { decahydrat }\end{array}$ & & & & & & & & 0.0 & 10.5 & 10.4 & 2.0 \\
e & & & & & & & 3 & 1 & 1 & 9 \\
\hline
\end{tabular}

\section{Physical and Mechanical Properties}

Figure 1(a) shows the evolution of bulk density with different SLS and BD composition for sample sintered at 1000 to $1150^{\circ} \mathrm{C}$ with results $1.6-2.4 \mathrm{~g} / \mathrm{cm}^{3}$ and $1.7-2.2 \mathrm{~g} / \mathrm{cm}^{3}$, respectively. At minimum composition and sintering temperature, SLS and BD that act as additional fluxing agent into stoneware will achieve maximum bulk density. SLS5 and BD10 achieved maximum bulk density $\left(2.4\right.$ and $\left.2.0 \mathrm{~g} / \mathrm{cm}^{3}\right)$ at $1100^{\circ} \mathrm{C}$ to $1050^{\circ} \mathrm{C}$ compared to ST $\left(2.3 \mathrm{~g} / \mathrm{cm}^{3}\right)$ at $1150^{\circ} \mathrm{C}$. From Figure 1(a), bulk density of SLS10 showed the highest value from $1000^{\circ} \mathrm{C}$ to $1050^{\circ} \mathrm{C}$ compared to SLS5. The additional $10 \mathrm{wt} \%$ of SLS produced a slight decrease in bulk density up to $2.3 \mathrm{~g} / \mathrm{cm}^{3}$ at $1100^{\circ} \mathrm{C}$ in the increase of content glassy phase. Previous investigation of Zhu et al., [18] reported, when large amount of fluxing agent was added, it increased the viscosity and produced more gas to remain in the sample and created more closed pores. The value of bulk density of ST increased with temperature. On the contrary, bulk density of SLS5, SLS10, and BD5 tend to steadily decrease at $1150^{\circ} \mathrm{C}$, while BD10 at $1100^{\circ} \mathrm{C}$.

Water absorption is the key factor that affects durability and directly correlates to the presence of open porosity as the result of incomplete viscous flow of glassy phase provided by flux. High value of water absorption indicates high degree of vitrification [19]. The samples of ST, SLS5, SLS10, BD5, and BD were sintered at different temperatures and the results of water absorption are shown in Figure 1(b). As seen, the water absorption ST decreases considerably with the increase of temperature. However, water absorptions of SLS5, SLS10, BD5, and BD10 initially decreased to its minimum value. Subsequently, the water absorption increased because of the expansion related to over sintering. Water absorption of ST from 2.5-18.4\% slightly decreased with the addition of SLS and BD that varied between 1.1-15.5\% and 0.4-16.6\% in 1000 to $1150^{\circ} \mathrm{C}$. The figure indicates that BD10 achieved the lowest water absorption $(0.4 \%)$ at $1050^{\circ} \mathrm{C}$ compared to $1150^{\circ} \mathrm{C}$ for ST $(2.5 \%)$, whereas $1100^{\circ} \mathrm{C}$ for SLS5 (1.1\%). Figure 1 (c) shows the modulus of rupture (MOR) of the sample sintered from 1000 to $1150^{\circ} \mathrm{C}$. 
For all compositions modified with SLS and BD, a higher value of modulus of rupture (MOR) is observed in comparison with ST. The increase in strength was due to higher content of sodium in soda-lime-silica glass and boron in borax decahydrate (shown in Table 1). However, the modulus of rupture (MOR) reached the maximum value for SLS5 $(63 \mathrm{MPa})$ and $\mathrm{BD} 10(51 \mathrm{MPa})$ at $1100^{\circ} \mathrm{C}$ and $1050^{\circ} \mathrm{C}$, respectively. The increased percentage in modulus of rupture (MOR) of SLS5 $\left(1100^{\circ} \mathrm{C}\right)$ and BD10 $\left(1050^{\circ} \mathrm{C}\right)$ in comparison with ST (48 MPa) at $1150^{\circ} \mathrm{C}$ was around 11-33 \%. In SLS5, modulus of rupture (MOR) for SLS10 and BD5 increased up to $1100^{\circ} \mathrm{C}$ before the decline. The increase of modulus of rupture (MOR) with temperature development up to $1100^{\circ} \mathrm{C}$ for SLS5, SLS10, BD5, and $1050^{\circ} \mathrm{C}$ for BD10 should be the result of the increasing glassy phase that was responsible for densification and quartz dissolution [20,21]. From the above discussion, minimum composition of SLS5 and BD10 had the highest bulk density, modulus of rupture (MOI and lower water absorption compared to ST. This minimum composition was selected for further discussion (SEM and XRD).

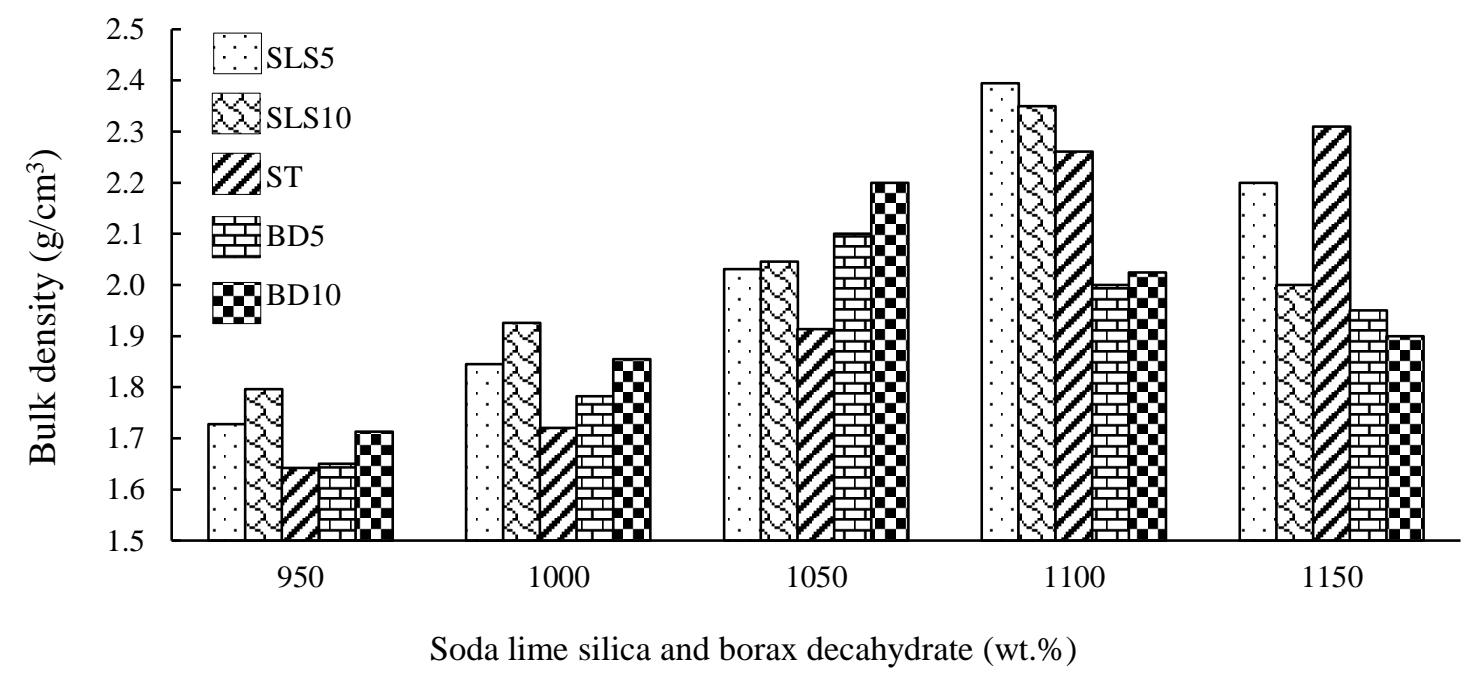

(a)

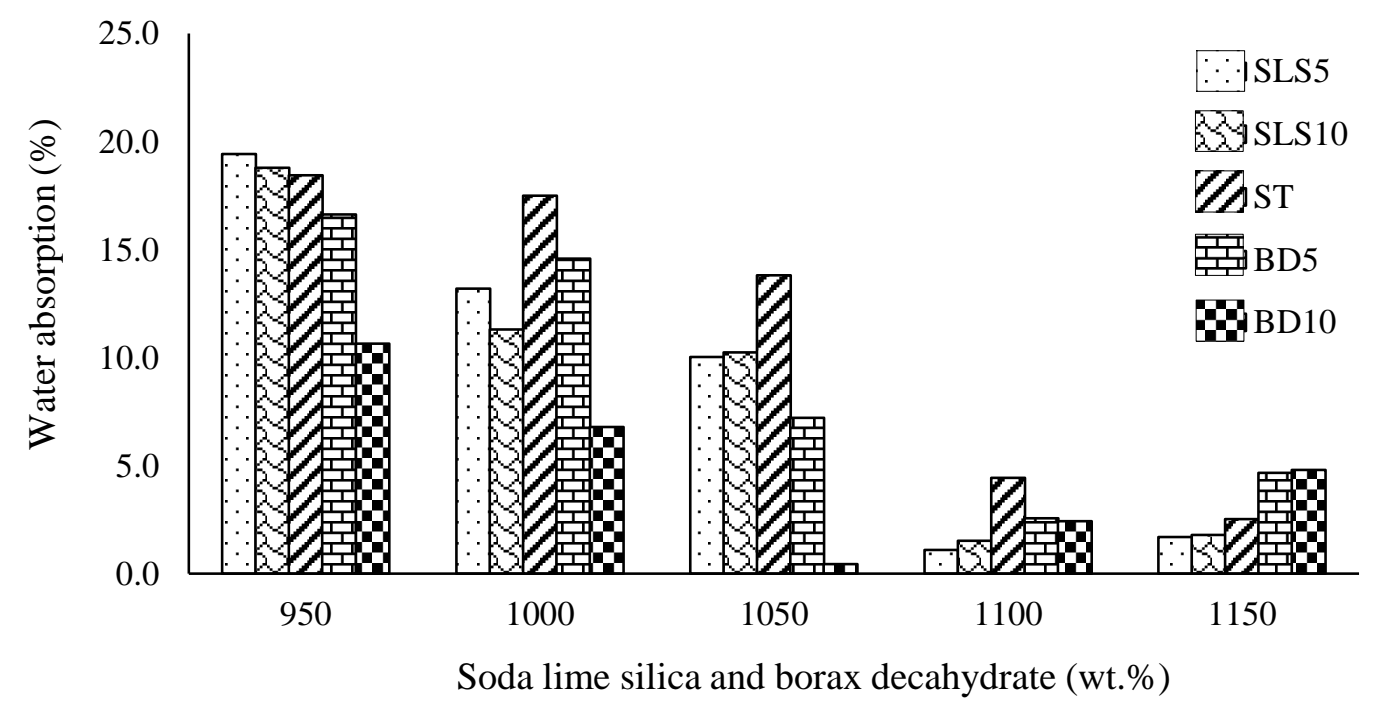

(b) 


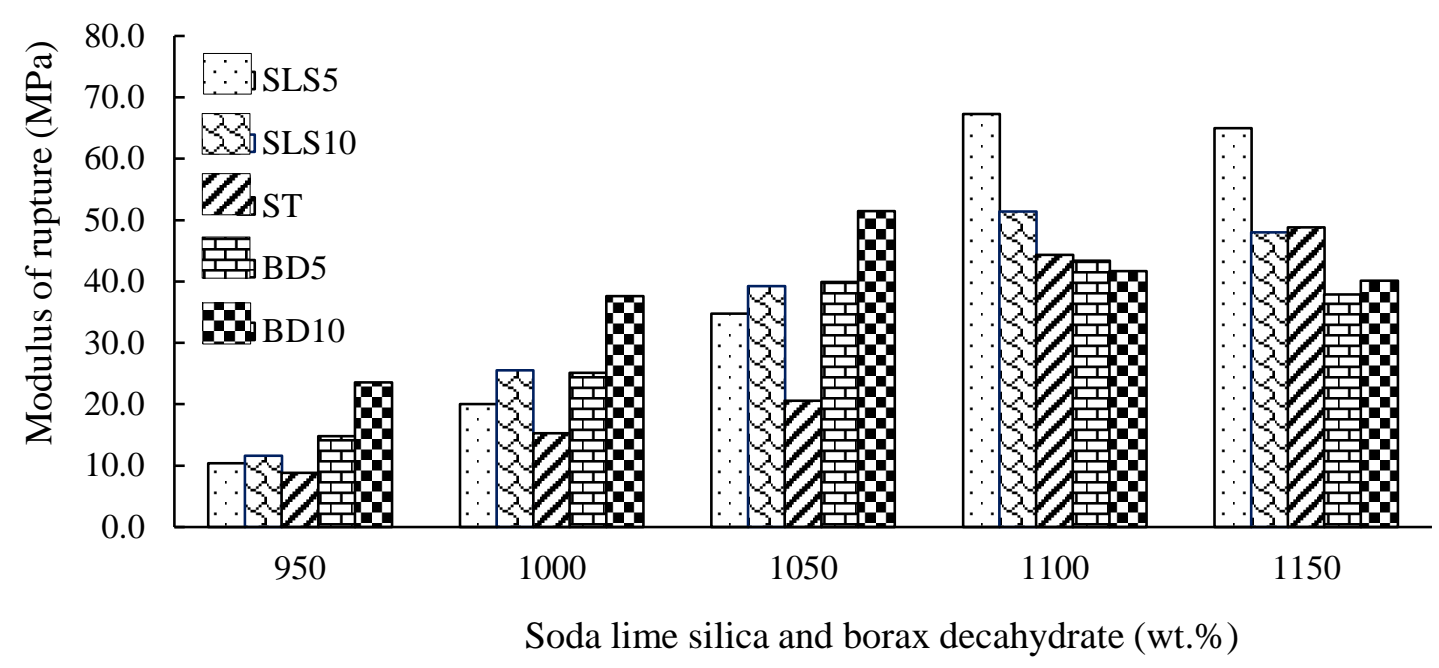

(c)

Figure 1. Plot of (a) bulk density, (b) water absorption and; (c) modulus of rupture as a function of SLS and BD.

\section{Microstructure and Mineralogical}

\section{Microstructure result of ST, SLS5 AND BD10}

The surface morphology of ST sintered at $1000^{\circ} \mathrm{C}$ to $1150^{\circ} \mathrm{C}$ is shown in Figure 2(a-d). Figure 2(a-c), it can be seen that there is high amount of pores with different irregular shapes at $1000^{\circ} \mathrm{C}$ to $1100^{\circ} \mathrm{C}$. ST sintered at $1150^{\circ} \mathrm{C}$ in Figure $2(\mathrm{~d})$ exhibited glassy matrix consisting of primary and secondary mullites. Figure 3(a-d) shows the surface morphology of SLS5 sintered at various temperatures. No change in morphology is seen SLS5 sintered at $1000^{\circ} \mathrm{C}$ and $1050^{\circ} \mathrm{C}$ in Figure 3(a-b), however consisted of fine and irregular shapes of open pore $<5 \mu \mathrm{m}$. When SLS5 was sintered up to $1100^{\circ} \mathrm{C}$ in Figure 3 (c), it was sufficient to lead the formation of glassy phase which can produce a better closure. Besides that, only primary mullite and quartz growth in SLS5 sintered at $1100^{\circ} \mathrm{C}$. As seen sample SLS5 sintered at $1150^{\circ} \mathrm{C}$ in Figure 3(d), the glassy matrix can clearly be seen which contain primary mullite, secondary mullite and quartz. Surface morphology of BD10 sintered at various temperatures obtained from SEM is shown in Figure 4(a-d). Based on Figure 4(a), BD10 sintered at $1000^{\circ} \mathrm{C}$ open pores are due to interconnected channel trough solid from surface and also incomplete densification process. When the sample was sintered at $1050^{\circ} \mathrm{C}$ in Figure 4(b), it created bubble formation on the surface of the sample. Moreover, when the sample was sintered at $1100^{\circ} \mathrm{C}$ and $1150^{\circ} \mathrm{C}$ in Figure 4(c-d), it creates surface deteriorated. Based on the Figure 2(a-d), Figure 3(a-d) and Figure 4(a-d), this observation support that open pore will affect the physical properties such as percentage of bulk density Figure 1(a), water absorption Figure 1(b), and modulus of rupture (MOR) based on Figure 1(c). 

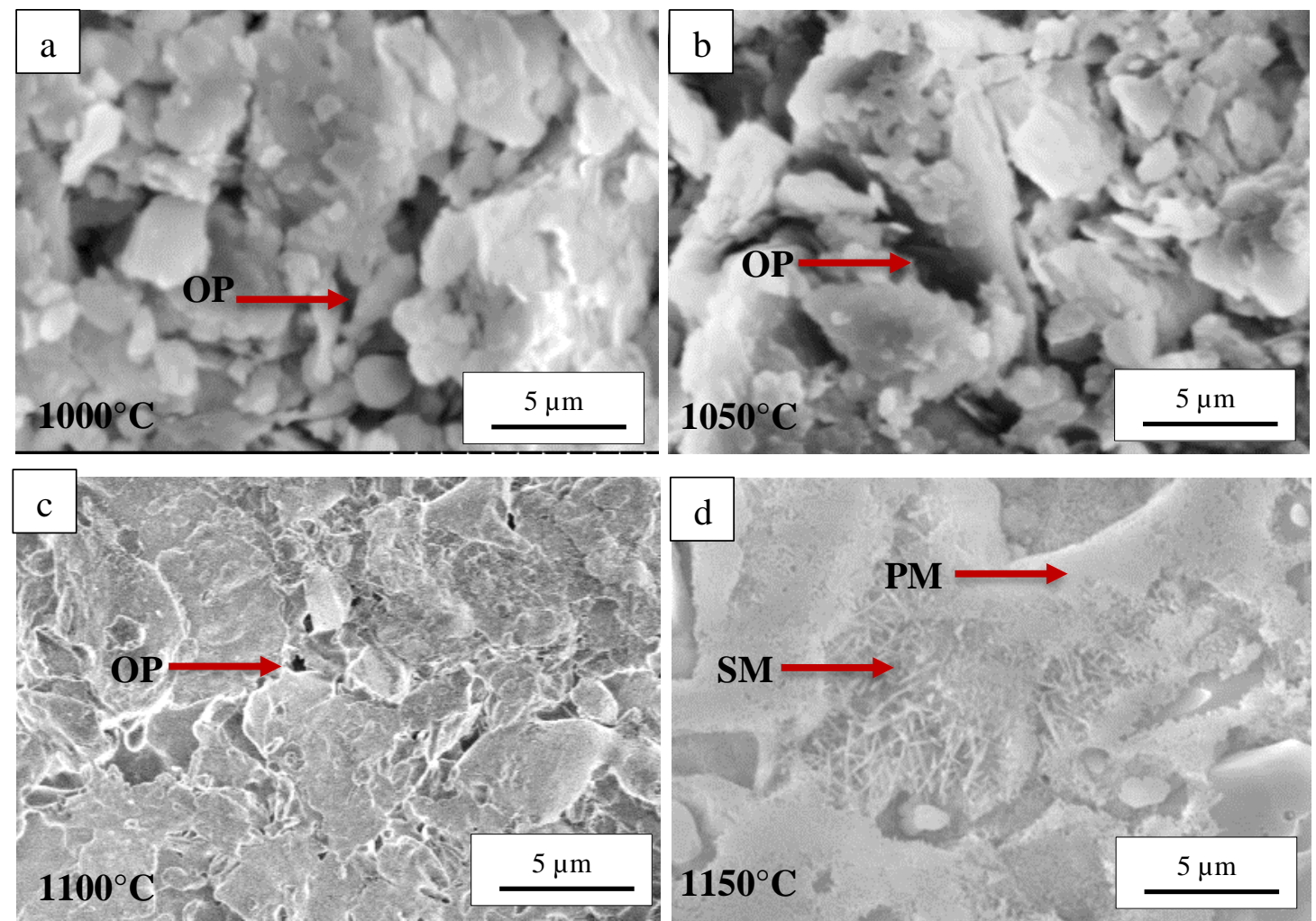

Figure 2.SEM morphology ST sintered :(a) $1000^{\circ} \mathrm{C}$; (b) $1050^{\circ} \mathrm{C}$; (c) $1100^{\circ} \mathrm{C}$; (d) $1150^{\circ} \mathrm{C}$ (OP: open pore, PM: primary mullite, $\mathrm{SM}$ : secondary mullite)
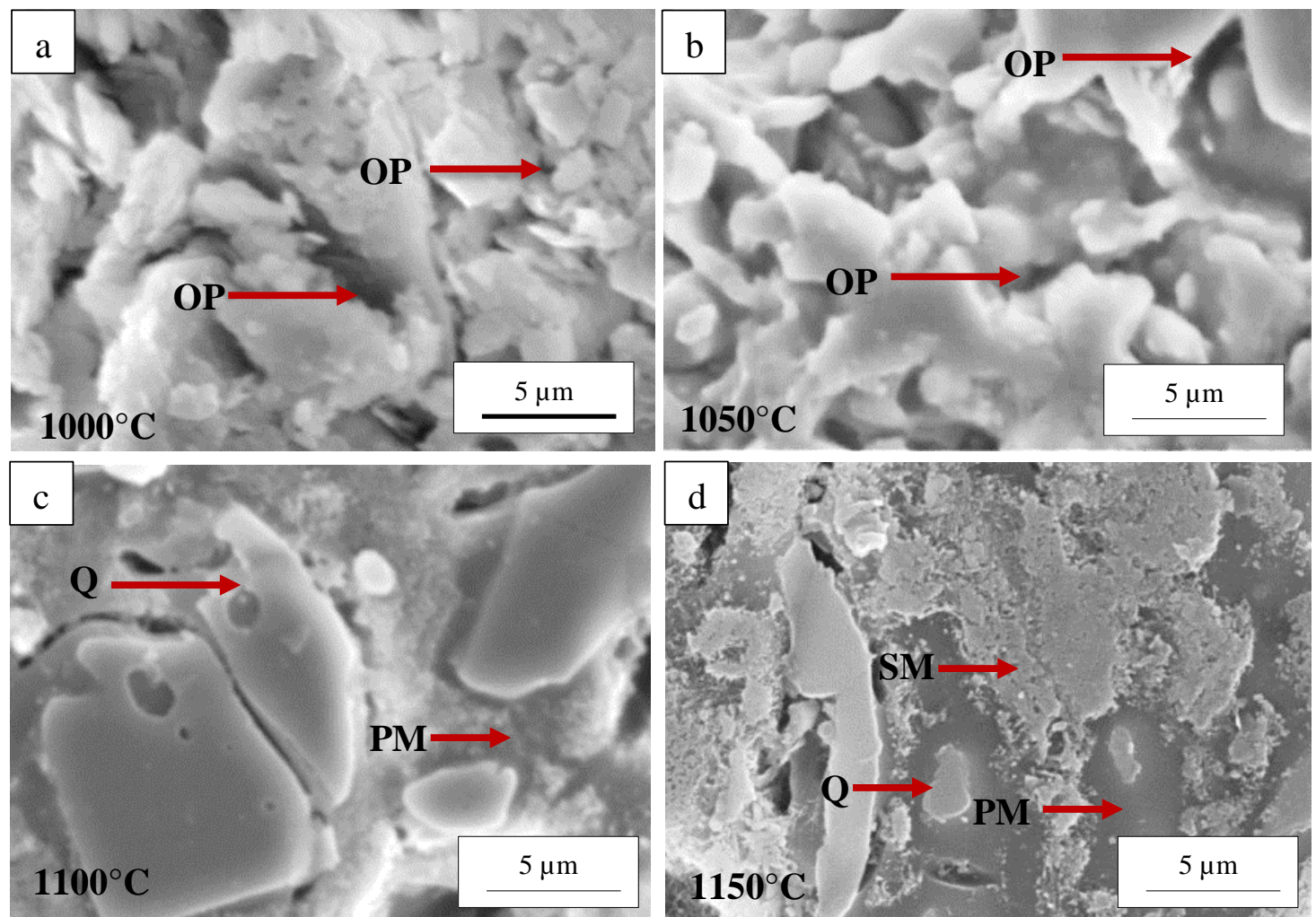

Figure 3.SEM morphology SLS5 sintered :(a) $1000^{\circ} \mathrm{C}$; (b) $1050^{\circ} \mathrm{C}$; (c) $1100^{\circ} \mathrm{C}$; (d) $1150^{\circ} \mathrm{C}$ (OP: open pore; Q: quartz; PM; primary mullite; SM; secondary mullite 

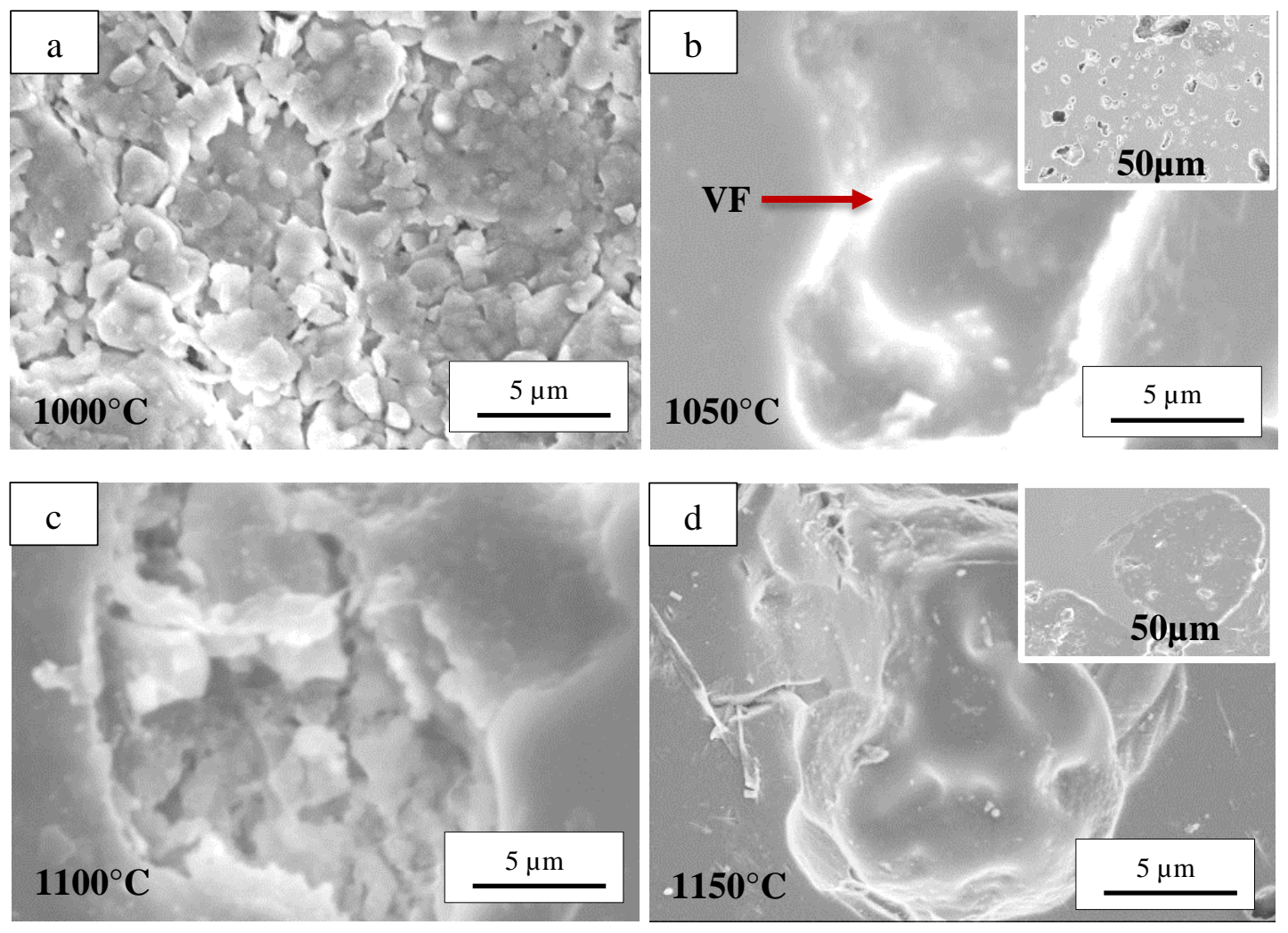

Figure 4. SEM morphology BD10 sintered :(a) $1000^{\circ} \mathrm{C}$, (b) $1050^{\circ} \mathrm{C}$, (c) $1100^{\circ} \mathrm{C}$ and; (d) $1150^{\circ} \mathrm{C}$ (VF: vitrified surface).

\section{Mineralogical result of ST, SLS5 and BD10}

Figure 5(a) to 5(c) illustrate the XRD pattern of ST, SLS5 and BD10 at various sintering temperatures. Figure 5(a) shows ST contains three main crystalline components which are mullite $\left(3 \mathrm{Al}_{2} \mathrm{O}_{3} .2 \mathrm{SiO}_{2}\right.$, JCPDS 001-0613), quartz ( $\mathrm{SiO}_{2}$, JCPDS 046-1045), and microline ( $\mathrm{KaAlSiO}_{3} \mathrm{O}_{8}$, JCPDS 001-0705). Sanidine ( $\mathrm{KaAlSiO}_{3} \mathrm{O}_{8}$, JCPDS 010-0357) is the new phase which occurred at $1150^{\circ} \mathrm{C}$, which might have been caused by the transformation of microline. Meanwhile, Figure 5(b) shows quite a different phase evolution as revealed by the XRD pattern SLS5 that contained three main crystalline components which are mullite, quartz, and labradorite ( $\mathrm{NaAlSiO}_{3} \mathrm{O}_{8}, \mathrm{JCPDS}$ 003-0499). Labradorite was $30-50 \%$ albite $\left(\mathrm{NaAlSiO}_{3} \mathrm{O}_{8}\right)$ or $50-70 \%$ anorthite $\left(\mathrm{CaAlSiO}_{3} \mathrm{O}_{8}\right)$ [1]. The formation of $\mathrm{NaAlSiO}_{3} \mathrm{O}_{8}$ was due to interaction between silica and alumina in stoneware with soda-lime-silica glass that contained the highest amount of $\mathrm{Na}_{2} \mathrm{O}$ $(18.17 \%)$ and $\mathrm{CaO}(6.92 \%)$ based on chemical composition in Table 1. Figure 5(c) shows the results of BD10 XRD pattern after sintering at $1000-1150^{\circ} \mathrm{C}$. The mineralogical examination based on XRD analysis revealed that the predominant phase in BD10 contained mullite, quartz, and albite $\left(\mathrm{NaAlSiO}_{3} \mathrm{O}_{8}\right)$. As in $\mathrm{BD} 10$, peak of albite and mullite were not present for sintered sample at $1150^{\circ} \mathrm{C}$. 


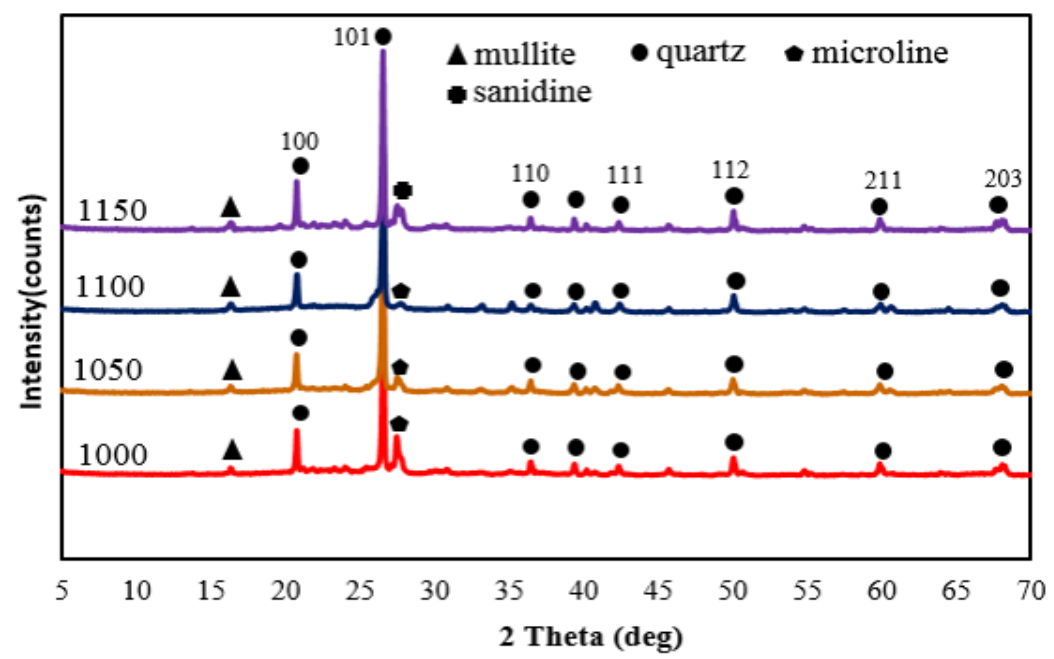

(a)

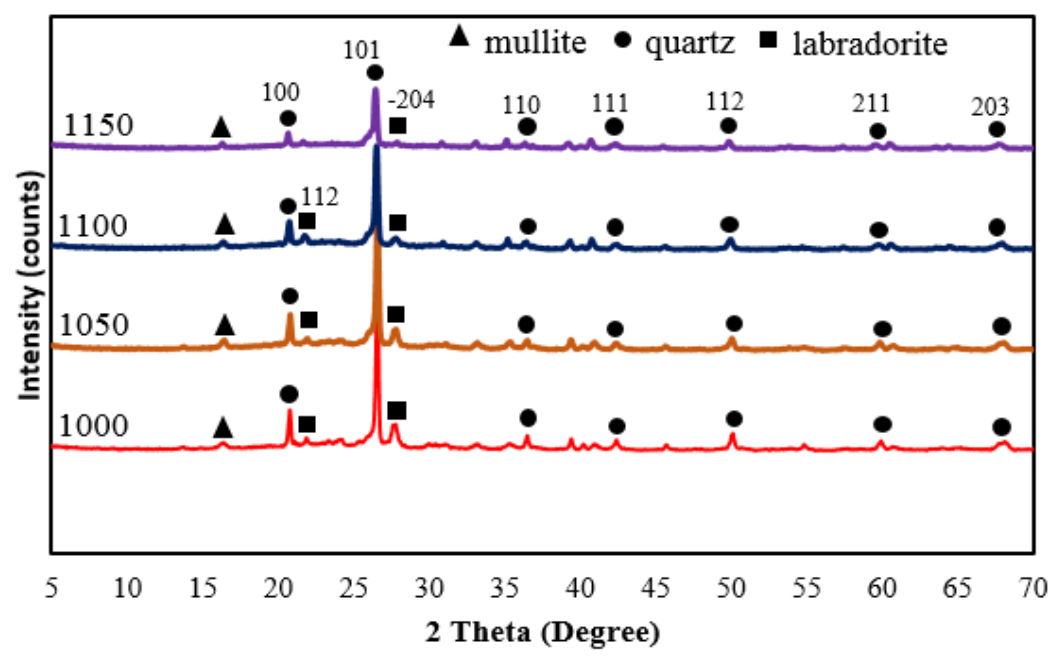

(b)

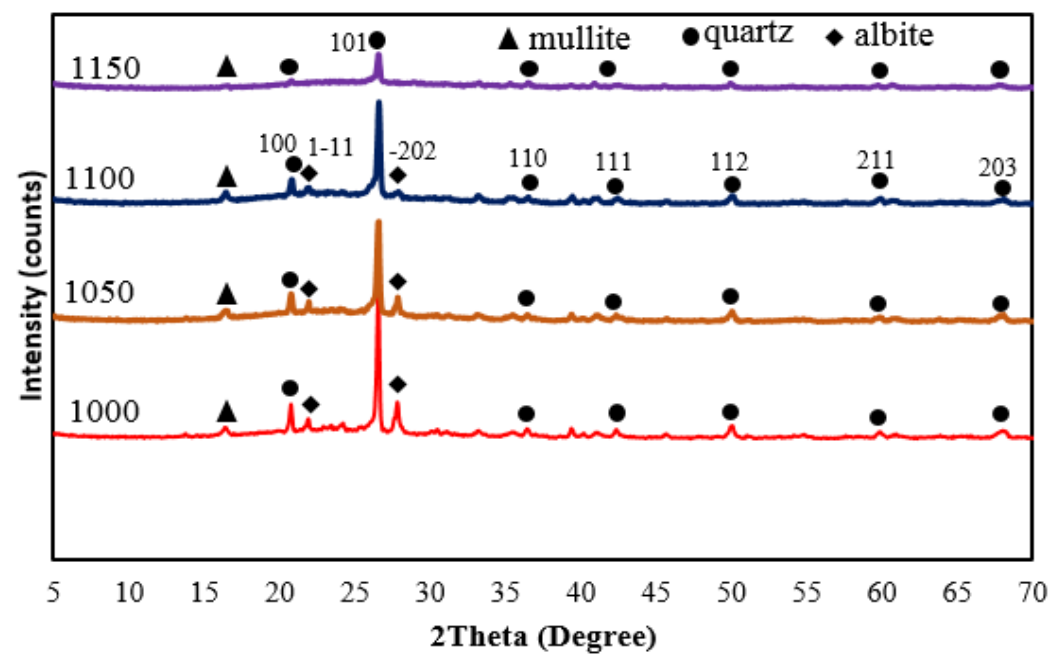

(c)

Figure 5. XRD pattern of (a) ST, (b) SLS5 and; (c) BD10. 
The presence of open pores in Figure 2(a) to 2(c), Figure 3(a) to 3(b) and Figure 4(a) resulted from insufficient amount of glassy phase associated with sintering temperature. According to Ke et al., [22] and Jaafar et al., [23], open pore is also related to incomplete densification process during sintering [19]. In Figure 3(a) to 3(b), as sintering temperature increased from $1000^{\circ} \mathrm{C}$ to $1050^{\circ} \mathrm{C}$, the inter particle neck also increased which led to less pores. However, the capability of glassy phase to react with solid particle was lower. Therefore, glassy phase could not flow into open pore by capillary pressure. Next, Figure 3(c) at minimum sintering temperature $1100{ }^{\circ} \mathrm{C}$ showed similar surface morphology with Figure $2(\mathrm{~d})$ at $1150^{\circ} \mathrm{C}$. Comparing the two results, it can be seen that only primary mullite presented in Figure 3(c). Based on chemical composition of soda lime silica in Table 1, the amount of $\mathrm{Al}_{2} \mathrm{O}_{3}$ was reduced. Therefore, there was insufficient $\mathrm{Al}_{2} \mathrm{O}_{3}$ to form secondary mullite [24]. On the other hand, Figure 4(b) to 4(c) at 1050 to $1150{ }^{\circ} \mathrm{C}$ shows vitrified surface. Element of sodium (Na) and boron (B) in BD based on chemical composition in Table 1 acted as modifiers with much lower energy to destroy the network structure of quartz that played an important role in the formation of vitrification [25, 26]. As evidence, from XRD pattern in Figure 5(c) the slightly decreasing peak of quartz was associated with partial dissolution and attributed to the fact that dissolute quartz in higher amount of glassy phase formed sodium (Na) and boron (B) in the mixture of BD10. These findings highlighted minimum sintering temperature when the glassy phase covered the entire sample surface and reacted with crystalline phase as suggested by Kamseu et al., [3]. Despite the glassy phase pulled toward densification, it also attributed to expansion of closed pore which arose from the entrapped gas such as nitrogen, carbon monoxide, and carbon dioxide. The results are in agreement with those obtained by Emrullahoglu [16] and Taksiran et al., [20].

Meanwhile, deteriorated surface in Figure 4(c) to $4(\mathrm{~d})$ sintered above $1050^{\circ} \mathrm{C}$ occurred because of boron that destroyed the structure of mullite which is the main crystalline of stoneware based on XRD in Figure 5(c). Comparison of the surface morphology showed that the evolution of microstructure depends on the type of flux and minimum sintering temperature. The heat treatment of SLS5 and BD10 at different sintering temperatures can be attributed to the change of glassy phase which leads to different ratio of glassy phase formed at peak temperature [27]. Partial replacement of SLS Figure 5(b) and BD Figure 5(c) had led to the formation of labradorite and albite instead of microline in ST Figure 5(a). The higher the sintering temperature, the lower the intensity of quartz peak $\left(2 \theta=20.86^{\circ}, 26.64,36.65^{\circ}, 42.9^{\circ}, 60.65^{\circ}\right.$ and $\left.68.4^{\circ}\right)$, labradorite $\left(2 \theta=23.58^{\circ}\right)$, and albite $\left(27.86^{\circ}\right)$. Based on the result, it can be assumed that the dissolution of quartz, labradorite, and albite was caused by high content of sodium, calcium, and boron in SLS and BD. Similar explanation has also been reported by Li et al., [28] that crystalline quartz decreased with incorporation of additional flux. This indicates that the additional of SLS and BD decreases the peak of quartz, labradorite and albite but does not enhance the mullite formation.

\section{CONCLUSION}

The effects of soda-lime-silica glass and borax decahydrate into stoneware are significant on bulk density, water absorption modulus of rupture (MOR), and microstructure. On the contrary, the amount of fluxing agent and sintering temperature are the key factors that need to be controlled. SLS5 sintered at $1100^{\circ} \mathrm{C}$ and BD10 sintered at $1050^{\circ} \mathrm{C}$ shows the minimum properties. In the comparison between SLS5 and BD10 as fluxing agent, SLS5 gives the highest bulk $\left(2.4 \mathrm{~g} / \mathrm{cm}^{3}\right)$ density and modulus of rupture $(63 \mathrm{MPa})$. Although 
morphology surface has proven $\mathrm{BD}$ as an effective additional fluxing agent because of the abundant glassy phase at $1050^{\circ} \mathrm{C}, \mathrm{BD}$ has the lowest water absorption $(0.4 \%)$ as it creates bubble on the surface of sample. All these demonstrate that the soda-lime-silica glass has better ability to be the additional fluxing agent in contrast with borax decahydrate.

\section{REFERENCES}

[1] Capoglu A. A novel low-clay translucent whiteware based on anorthite. Journal of the European Ceramic Society 2011; 31: 321-329.

[2] Lassinantti Gualtieri, Mugoni, C, Guandalini S, Cattini A, Mazzini D, Alboni C, Siligardi. Glass recycling in the production of low-temperature stoneware tiles. Journal of Cleaner Production 2018; 197: 1531-1539.

[3] Kamseu E, Leonelli C, Boccaccini DN, Veronesi P, Miselli P, Pellacani, Melo UC. Characterization of porcelain compositions using two china clays from Cameroon. Ceramics International 2017; 5: 851-857.

[4] Perez JM, Romero M. Microstructure and technological properties of porcelain stoneware tiles molded at different pressures and thicknesses. Ceramics International 2014; 40(1): 1365-1377.

[5] Bernardo E, Esposito L, Rambaldi E, Tucci A. Glass based stoneware as a promising route for the recycling of waste glasses. Advances in Applied Ceramics 2009; 108.

[6] Luz A, Ribeiro S. Use of glass waste as raw material in porcelain stoneware tile mixture. Ceramics International 2007; 33: 761-765.

[7] Sokolar R, Sveda M. The use of zeolite as fluxing agent for whitewares. Procedia Engineering 2016; 15: 229-235.

[8] Acchar W, Dultra EJV, Segadaes AM. Untreated coffee husk ashes used as flux in ceramic tiles. Applied Clay Science 2013; 75(76): 141-147.

[9] Wattanasiriwech D, Wattanasiriwech S. Fluxing action of illite and microcline in a triaxial porcelain body. Journal of the European Ceramic Society 2011; 31: 1371-1376.

[10] Marinoni N, Diella V, Confalonieri G, Pavese A, Francescon F. Soda-lime-silicaglass/quartz particle size and firing time: Their combined effect on sanitary-ware ceramic reactions and macroscopic properties. Ceramics International 2017; 43(14): 10895-10904.

[11] Akpinar S, Yazici ZO, Can MF. Investigation of surface-modified anhydrous borax utilisation in raw glazes. Ceramics International 2018; 44(15): 1834418351.

[12] Phonphuak N, Kanyakam S, Chindaprasirt P. Utilization of waste glass to enhance physical-mechanical properties of fired clay brick. Journal of Cleaner Production 2016; 112(4): 3057-3062.

[13] Marinoni N, DAlessio D, Diella V, Pavese A, Francescon F. Effects of soda lime-silica waste glass on mullite formation kinetics and micro-structures development in vitreous ceramics. Journal of Environmental Management 2013; 124: 100-107.

[14] El- Shimy YN, Amin SK, El-Sherbiny SA, Abadir MF. The use of cullet in the manufacture of vitrified clay pipe. Construction and Building Material, 2014; 73: 452-457. 
[15] Owoeye SS, Toludare TS, Isinkaye OE, Kingsley U. Influence of waste glasses on the physico-mechanical behavior of porcelain ceramics. Boletín de La Sociedad Española de Cerámica y Vidrio 2018.

[16] Emrullahoglu Abi CB. Effect of boron gypsum on brick properties. Construction and Building Materials, 2014; 5: 195-203.

[17] Bayca SU. Effects of the addition of ulexite to the sintering behavior of a ceramic body. Journal of Ceramic Processing Research 2009; 10: 162-166.

[18] Zhu M, Ji R, Li Z, Wang H, Liu L, Zhang Z. Preparation of glass ceramic foams for thermal insulation applications from coal fly ash and waste glass. Construction and Building Materials 2016; 112: 398-405.

[19] Mustafi S, Ahsan M, Dewan AH, Ahmed S, Khatun N, Absar N. Effect of waste glass powder on physico-mechanical properties of ceramic tiles. Bangladesh Journal of Scientific Research 2012; 24:169-180.

[20] Taskiran MU, Demirkol N, Capoglu A. A new porcelainised stoneware material based on anorthite. Journal of the European Ceramic Society 2015; 25: 293-300.

[21] Baldo J, Dos Santos W. Phase transitions and their effects on the thermal diffusivity behaviour of some SiO2. Polymorphs Ceramic 2002; 307: 172-177.

[22] Ke S, Wang Y, Pan Z, Ning C, Zheng S. Recycling of polished tile waste as a main raw material in porcelain tiles. Journal of Cleaner Production 2016; 115: 238-244.

[23] Jaafar M, Razak KA, Ariff ZM, Zabidi H, Yahya H, Othman MR, Ahmad ZA. Effect of mullite formation on properties of aluminosilicate. Ceramic Balls Procedia Chemistry 2016; 19: 922-928.

[24] Eliche-Quesada D, Azevedo-Da Cunha R, Corpas-Iglesias FA. Effect of sludge from oil refining industry or sludge from pomace oil extraction industry addition to clay ceramics. Applied Clay Science 2015; 114: 202-211.

[25] Yu Y, Hao X, Song L, Li Z, Song L. Synthesis and characterization of single phase and low temperature co-fired cordierite glass-ceramics from perlite. Journal of Non-Crystalline Solids, 2016; 448: 36-42.

[26] Prasad CS, Maiti KN, Venugopal R. Effect of rice husk ash in whiteware compositions. Ceramics International 2001; 27: 629-635.

[27] Matteucci F, Dondi M, Guarini G. Effect of soda-lime glass on sintering and technological properties of porcelain stoneware tiles. Ceramics International 2002; 28: 873-880.

[28] Li N, Zhang XY, Qu YN, Xu J, Ma N, Gan K, Yang JL. A simple and efficient way to prepare porous mullite matrix ceramics via directly sintering $\mathrm{SiO}_{2}-\mathrm{Al}_{2} \mathrm{O}_{3}$ microspheres. Journal of the European Ceramic Society 2016; 36: 2807-2812. 